Menyemai Benih Karakter Wirausaha

\title{
Menyemai Benih Karakter Wirausaha \\ (Internalisasi Karakter Wirausaha Sejak Dini Melalui Pelatihan Bagi Guru Dan Orang Tua)
}

\author{
Kiromim Baroroh ${ }^{1}$
}

\begin{abstract}
Abstrak
Penelitian ini bertujuan untuk mengetahui a. pelaksanaan kegiatan pelatihan menanamkan karakter wirausaha di Kelompok Bermain Cendekia b. Faktor pendorong dan penghambat pelatihan internalisasi karakter wirausaha di Kelompok Bermain Cendekia.

Penelitian ini menggunakan pendekatan kualitatif yang dilakukan di Kelompok Bermain (KB) Cendekia,Ketandan Jetis Bantul. Informan penelitian meliputi: peserta pelatihan, yaitu orang tua wali dan guru yang berjumlah 22 orang dan 4 orang tutor. Teknik pengumpulan data yang digunakan adalah: Wawancara, pengamatan/observasi, dan dokumentasi. Langkah dalam menganalisis data, yaitu (1) reduksi data; (2) sajian data; dan (3) penarikan kesimpulan atau verifikasi. Dalam penelitian ini peneliti menggunakan analisis selama pengumpulan data.

Hasil penelitian adalah: 1) Kegiatan pelatihan ini dapat dijadikan sarana untuk meningkatkan kemampuan orang tua dan guru untuk melakukan inovasi-inovasi baru dalam hal penanaman jiwa wirausaha anak sejak dini yang nampak pada hasil pelatihan yang menunjukkan: Sebagian besar peserta memiliki sikap positif terhadap pelaksanaan pelatihan. ditunjukkan: a) Sebagian besar peserta memiliki sikap positif terhadap pelaksanaan pelatihan yang diunjukkan dari hasil observasi sebagian besar (95\%) guru dan orang tua serius serta antusias. b) Dilihat dari tingkat pemahaman terhadap materi pelatihan menunjukkan bahwa $95 \%$ peserta paham dalam materi pelatihan. Hal ini nampak pada saat diberi pertanyaan tentang materi, $95 \%$ berhasil menjawab dengan baik. c) dalam pelatihan peserta $88 \%$ dari seluruh guru dan orang tua yang diundang mengikuti kegiatan. d) Berdasarkan observasi dan wawancara terdapat peningkatan jiwa wirausaha pada orang tua dan guru. Peserta semakin percaya diri ketika diberi tugas oleh instruktur. e) Dilihat dari jiwa wirausaha menunjukkan bahwa semua peserta nampak antusias dan percaya diri untuk berlatih mempraktikkan materi yang diterima dalam pembelajaran di kelas maupun saat mengajar anak didiknya. 2) Faktor pendukung pelatihan adalah: a) Semangat dan motivasi para peserta untuk maju dan terus meningkatkan kemampuan mengasuh siswa dan anak, khususnya dalam upaya meningkatkan kualitas belajar dan pembelajaran bagi anak/peserta didiknya. b) Dukungan (support) pengurus KB Cendekia dan kepala sekolah

\footnotetext{
${ }^{1}$ Dosen pendidikan ekonomi FISE UNY. S1 Pendidikan Ekonomi UNY, S2 Penelitian dan Evaluasi Pendidikan UNY
} 
serta untuk kelancaran kegiatan-kegiatan dalam bentuk pemberian dukungan fasilitas tempat dan kegiatan. Sedangkan faktor penghambat yaitu: waktu yang relative panjang untuk mempersiapkan materi pembelajaran terutama untuk materi yang baru, serta adanya kegiatan yang bersamaan dengan kegiatan guru sehingga ada beberapa peserta yang diundang tidak dapat datang.

Kata kunci: pelatihan, wirausaha, guru, orang tua

\section{A. Pendahuluan}

Untuk mengantisipasi dampak terjadinya krisis ekonomi, salah satu usaha yang dapat dilakukan adalah perlu ditumbuhkembangkan budaya kewirausahaan di seluruh lapisan masyarakat termasuk di lingkungan pendidikan formal maupun non formal maupun informal termasuk pendidikan di lingkungan keluarga dan masyarakat.

Karakter wirausaha dapat pula disebut watak wirausaha, tidak dapat dikembangkan secara instan. Perlu pendidikan yang kontinyu untuk mngembangkan potensi watak kewirausahaan anak. Selama ini pendidikan orang tua cenderung lebih pada upaya melindungi anak agar tidak mendapat celaka, orang tua cenderung memanjakan anak. Dengan memanjakan anak dan kuranagmemberi ruang pada anak untuk mengembangkan kreativitas dan kemandirian menyebabkan anak kelak dikemudian hari tidak dapat menjadi orang yang mandiri, kreatif dan berani mengambil resiko. Mandiri, kreatif dan berani mengambil resiko merupakan sebagian dari ciri-ciri karakter wirausaha.

Peran orang tua sangat penting dalam mengembangkan karakter wirausaha sejak dini. Namun tidak semua orang tua memahami karakter ini dengan baik. Salah satu upaya untuk menambah wawasan kewirausahaan orang tua dan guru tentang bagaimana cara mendidik anak yang berwawasan kewirausahaan adalah melalui pelatihan. Salah satu intitusi yang sudah melakukan pelatihan ini adalah Kelompok Bermain Cendekia.

Penelitian ini bertujuan untuk mengetahui a. bagaimana pelaksanaan kegiatan pelatihan internalisai karakter wirausaha di Kelompok Bermain Cendekia? Faktor pendorong dan penghambat pelatihan penanaman karakter wirausaha di Kelompok Bermain Cendekia?

\section{B Landasan Teori}

\section{Pengertian dan Ciri-ciri Wirausaha}

Istilah kewirausahaan kata dasarnya berasal dari terjemahan entrepreneur. Robert D Hisrich, dkk (2010:8) mendefinisikan enterpreneurship is the process of creating something new with value by devoting the necessary time and effort, assuming the accompanying financial, psychic, and social risk, and receiving the resulting rewards of monetary and personal satisfaction and independence.

Buchari Alma (2007: 24) memberikan definisi wirausaha 
adalah orang yang melihat adanya peluang kemudian mencipatakan sebuah organisasi untuk memanfaatkan peluang tersebut. Pengertian wirausaha di sini menekankan setiap orang yang memulai sesuatu bisnis yang baru. Sedangkan proses kewirausahaan meliputi semua kegiatan fungsi dan tindakan untuk mengejar dan memanfaatkan peluang dan menciptakan suatu organisasi.

Dalam definisi tersebut ditekankan bahwa wirausaha adalah orang yang melihat adanya peluang kemudian menciptakan sebuah organisasi untuk memanfaatkan peluang tersebut. Istilah wirausaha dan wiraswasta sering digunakan secara bersamaan, walaupun memiliki substansi yang agak berbeda.http:/ / www.geocities.com Lagus_lecturer/kewirausahaan/def insi_kewirausahaan.htm.

Kewirausahaan tidak dapat dilepaskan dengan kreativitas.

Kreativitas merupakan

kekampuan seseorang untuk menghasilkan komposisi, produk, atau gagasan apa saja yang pada dasarnya baru, dan sebelumnya tidak dikenal pembuatnya (Elizabeth B. Hurlock, 2005: 4)

Menjadi manusia yang kreatif dan inovatif merupakan dambaan setiap orang. Rata-rata orang yang sukses memiliki sikap ini. Namun ternyata tidak semua orang memilikinya. Butuh waktu yang panjang dan usaha keraas untuk menjadi kreatif dan inovatif. Setiap manusia mempunyai potensi untuk menjadi kreatif dan inovatif. Hanya bagaimana dia mampu mengembangkan potensi tersebut. Pembentukan dan pengembangan potensi tersebut dapat dilakukan melalui proses pendidikan, pelatihan, uji coba, dan praktik nyata.

Ciri-ciri pribadi yang kreatif adalah:
a. Imajinatif

b. Mempunyai prakarsa

c. Mempunyai minat luas

d. Mandiri dalam berfikir

e. Melit(ingin tahu)

f. Senang berpetualang

g. Penuh energi

h. Percaya diri

i. Bersedia mengambil resiko

j. Berani dalam pendirian dan keyakinan

Ada beberapa faktor yang mempengaruhi dalam upaya mengembangkan potensi tersebut berasal dari faktor internal dan eksternal. Yang merupakan faktor internal adalah:

a. Adanya keinginan merubah diri. Dari tidak dapat menjadi dapat, dari tidak mampu menjadi mampu.

b. Menghindari rasa puas dengan keadaan dan memandang kehidupan masih panjang

c. Belajar dan berlatih dengan mulai dari hal kecil dan sederhana.

d. Adanya kebebasan untuk berekspresi

Adapun faktor eksternal (dari luar) adalah: 
a. Pembimbing yang berwawasan luas dan kreatif

b. Tersedia sarana dan prasarana

c. Kondisi lingkungan yang harmonis, baik di lingkungan keluarga, teman sebaya, masyarakat maupun sekolah.

Untuk menjadi kreatif dan inovatif tidaklah semudah membalik telapak tangan. Banyak hambatan yang menjadi kendaa. Faktor-faktor yang menjadi hambatan dapat berupa faktor internal maupun eksternal. Antara lain adalah:

a. Terbelenggu sifat malas, sehingga hilang kemauan, semangat, dan motivasi

b. Takut salah dan gagal

c. Rasa malu pada orang lain

d. Merasa puas dengan apa yang sudah ada atau teah dianggap baik

e. Suasana ligkungan yang tidak mendukung kegiatan kreativitas dan inovasi

f. Suka menyia-nyiakan waktu uang

g. Kurangnya penghargaan atas hasil gagasan kreatif dan inovatif

h. Bersikap santai karena merasa cukup

i. Minimnya atribut-atribut yang dapat menumbuhkembangkan semangat untuk menjadi kreatif dan inovatif

Hambatan tersebut, masih terdapat penghalang berfikir kreatif, yaitu:

a. Tidak mau mengubah sudut pandang b. Kita terbiasa melihat sesuatu berdasarkan fungsinya. Contoh: Sapu tangan digunakan untuk membersihkan tangan, padahal sapu tangan dapat juga digunakan untuk membersihkan muka, penutup muka, dan lain sebagainya. Contoh yang lain sebuah perusahaan pembangunan rumah mengalami kesulitan, lamanya mendirikan rumah yang tidak sesuai dengan kontrak. Ini terjadi karena para buruh bangunan sengaja berlama-lama agar merraaka memperoleh uang lembur. Akhirnya pimpinan perusahaan membuat kebijakan baru. Bonus bukan diberikan pada pekerja yang bekerja lama, namun justru pada mereka yang bekerja cepat.

c. Enggan menerima perubahan Sejumlah ide langsung kita buang dan lupakan begitu dimunculkan. Kita membayangkan harus melakukan banyak perubahan drastis. Pada hal kita belum melakukannya. Kita mempunyai ide untuk membawa makanan dari rumah dari pada jajan.kita berharap dapat menabung. Ide itu segera kita buang karena kita harus repot mempersiapkannya dari rumah.

d. Merasa tidak berdaya

Untuk menjadi kreatif tidak harus jenius. Wight 
| Menyemai Benih Karakter Wirausaha

bersaudara yang menemukan pesawat bukanlah insinyur. Mereka adalah tukang memperbaiki sepeda. e. Takut ditertawakan (Ikhsan \& Ariyanti, 2005:164)

Berikut ini tabel tentang ciriciri wirausaha

Tabel: Ciri-ciri wirausahawan

\begin{tabular}{|l|l|}
\hline \multicolumn{1}{|c|}{ Ciri-ciri } & \multicolumn{1}{c|}{ Watak } \\
\hline Percaya diri & $\begin{array}{l}\text {-kepercayaan (keteguhan) } \\
\text {-ketidaktergantungan, kepribadian mantap } \\
\text {-optimisme }\end{array}$ \\
\hline $\begin{array}{l}\text { Berorientasikan } \\
\text { tugas dan hasil }\end{array}$ & $\begin{array}{l}\text {-kebutuhan atau haus akan prestasi } \\
\text {-berorientasi laba atau hasil } \\
\text {-tekun dan tabah } \\
\text {-tekad,kerja keras,motivasi } \\
\text {-energik } \\
\text {-Penuh inisiatif }\end{array}$ \\
\hline Pengambil resiko & $\begin{array}{l}\text {-mampu mengambil resiko } \\
\text {-suka pada tantangan }\end{array}$ \\
\hline kepemimpinan & $\begin{array}{l}\text {-mampu memimpin } \\
\text {-dapat bergaul dengan orang lain } \\
\text {-menanggapi saran dan kritik }\end{array}$ \\
\hline keorisinilan & $\begin{array}{l}\text {-inovatif (pembaharu) } \\
\text {-kreatif } \\
\text {-fleksibel } \\
\text {-banyak sumber } \\
\text {-serba bisa } \\
\text {-mengetahui banyak }\end{array}$ \\
\hline Berorientasi \\
masa depan
\end{tabular}

BN Marbun dalam Buchari Alma, 2007: 52

\section{Pelatihan}

Salah satu upaya menumbuhkan karakter wirausaha adalah melalui pelatihan. Salah satu tujuan pelatihan adalah mengetahui efektivitas pelatihan. Cara yang digunakan adalah melalui penilaian efektivitas pelatihan. Leslie Rae (1990: 3) memberikan definisi penilaian efektifitas pelatihan adalah suatu istilah untuk memastikan apakah pelatihan dijalankan dengan efektif dan efisien dalam mencapai sasaran yang dilakukan, yang mencakup evaluasi dan validasi.

Dalam evaluasi pelatihan, harus menjawab pertanyaan berikut ini:

a. apakah pelatihan mencapai sasaran

b. apakah pelatihan memenuhi kebutuhan klien 
c. apakah ada perbedaan dalam cara kerja mereka sebagai akibat dari pelatihan itu?

d. adakah perilaku yang berbeda itu disebabkan oleh pelatihan yang diikuti?

e. apakah pelajaran yang diperoleh diterapkan dalam situasi pekerjaan yang sebenarnya?

f. Apakah pelatihan membantu menghasilkan seseorang pekerja yang lebih efektif dan efisien

g. Apakah pelatihan telah membantu membentuk organisasi yang lebih efektif dan efisien? (Leslie Rae, 1990:4).

\section{Metode Penelitian}

1. Pendekatan Penelitian

Penelitian ini menggunakan pendekatan kualitatif di mana peneliti menekankan pada manusia serta melihat secara langsung keadaan yang ada tanpa mengubah peristiwa yang terjadi di lapangan, dan setelah di rumah peneliti membuat catatan lapangan, seperti yang dikatakan Lincoln dan Guba (1985 : 40) bahwa penelitian kualitatif digunakan untuk dapat menjelaskan atau mengungkapkan secara langsung atau alamiah apa yang terjadi di lapangan. Oleh karena itu peneliti dapat secara langsung menginventarisasi data dari peserta pelatihan, dan tutor pelatihan,.

2. Setting Penelitian

Penelitian dilakukan di Kelompok Bermain Cendekia,Ketandan Jetis Bantul.
Dilaksanakan pada bulan April sampai Agustus 2010.

3. Informan Penelitian

Peserta pelatihan, yaitu orang tua wali Play Group Kelompok Bermain Cendekia, Dusun Ketandan Desa Patalan Kecamatan Jetis kabupaten Bantul. Informan penelitian adalah peserta pelatihan sebanyak 22 orang orang tua dan guru Kelompok Bermain Cendekian dan sekitarnya, serta 4 orang tutor.

4. Teknik Pengumpulan Data

Dalam penelitian ini teknik pengumpulan data yang digunakan adalah:

a. Wawancara

Wawancara adalah dengan maksud tertentu yang dilakukan oleh dua pihak yaitu pewawancara (interviewer) dan yang diwawancarai (intererviewee) (Moleong, 2004: 135). Wawancara dimaksudkan untuk mengumpulkan data dengan berdialog dengan informan. Peneliti melakukan wawancara sehingga terjadi hubungan yang akrab antara peneliti dengan yang diwawancarai. Dengan keadaan yang demikian peneliti dapat mengembangkan pertanyaan agar dapat memperoleh informasi yang rinci, jujur dan mendalam. Wawancara seperti ini dalam penelitian kualitatif dikenal dengan wawancara mendalam (indepth interview).

Pada pendekatan wawancara informal pertanyaan yang diajukan sangat tergantung pada pewawancara sendiri (Moleong, 2004: 136). Sementara pendekatan dengan petunjuk umum wawancara digunakan atas anggapan bahwa ada jawaban yang secara umum akan sama diberikan oleh para 
responden, tetapi yang jelas tidak ada perangkat pertanyaan baku yang disiapkan terlebih dahulu (Moleong, 2004: 136). Dalam penelitian kualitatif peneliti adalah alat pengumpul data yang utama. Oleh karena itu agar informasi yang diberikan oleh informan dapat dicatat dengan baik dalam catatan lapangan dan tape recorder.

b. Pengamatan

Pengamatan adalah teknik pengumpulan data dengan mengamati objek penelitian secara langsung. Dalam penelitian kualitatif, pengamatan dimanfaatkan untuk (1) pengamatan didasarkan atas pengalaman secara langsung; (2) pengamatan memungkinkan melihat dan mengamati sendiri, kemudian mencatat perilaku dan kejadian dalam keadaan yang sebenamya; (3) pengamatan memungkinkan mencatat peristiwa dalam situasi yang berkaitan dengan pengetahuan proporsional; (4) ada keraguan jangan-jangan data yang dijaring melenceng atau bias, dan perlu dicek dengan pengamatan; (5) memungkinkan peneliti mampu memahami situasi yang sulit; (6) dalam kasus-kasus tertentu di mana teknik lain tidak memungkinkan, maka dapat digunakan pengamatan (Lincoln dan Guba, 1985: 125-126).

\section{c. Dokumentasi}

Menurut Lincoln dan Guba (1985 : 228) dokumentasi adalah setiap bahan tertulis ataupun film. Sedangkan record adalah setiap pernyataan tertulis yang disusun oleh seseorang atau lembaga untuk keperluan pengujian suatu peristiwa atau menyajikan akunting. Teknik dokumentasi dimanfaatkan untuk mengadakan verifikasi dan triangulasi data yang diperoleh melalui observasi dan wawancara.

\section{Analisis Data}

Teknik analisis data adalah salah satu aspek yang dilakukan untuk mendapatkan makna dari kumpulan data. Dalam penelitian kualitatif ada tiga langkah dalam menganalisis data, yaitu (1) reduksi data; (2) sajian data; dan (3) penarikan kesimpulan atau verifikasi (Miles dan Huberman, 1994: 10-12). Ketiga komponen dalam analisis data tersebut selalu berkaitan antara satu dengan yang lain. Dalam penelitian ini peneliti menggunakan analisis selama pengumpulan data.

\section{Uji Keabsahan Data}

Peneliti dalam memeriksa keabsahan data menggunakan teknik trianggulasi data. Penelitian ini menggunakan trianngulasi metode sumber. Pengertian kedua triangulasi tersebut adalah sebagai berikut:

a. Trianggulasi Sumber

Trianggulasi sumber atau data adalah membandingkan dan mengecek balik derajat kepercayaan suatu informasi yang diperoleh melalui waktu dan alat yang berbeda dalam metode kulitatif. Menurut Moleong (2004: 178) hal ini dapat dicapai dengan jalan: (1) membandingkan data hasil pengamatan dengan data hasil 
wawancara, (2) membandingkan apa yang dikatakan orang di depan umum dengan apa yang dikatakannya secara pribadi, (3) membandingkan apa yang dikatakan orang-orang tentang situasi penelitian dengan apa yang dikatakannya sepanjang waktu, (4) membandingkan keadaan dan perspektif seseorang dengan berbagai pendapat dan pandangan orang sebagai rakyat biasa, orang yang berpendidikan menengah atau tinggi, orang berada, orang pemerintahan, (5) membandingkan hasil wawancara dengan isi suatu dokumen. b. Triangulasi metode Menurut Patton (1982: 329), terdapat dua strategi yaitu: (1) pengecekan derajat kepercayaan penemuan hasil penelitian beberapa teknik pengumpulan data dan (2) pengecekan derajat kepercayaan beberapa sumber data dengan metode yang sama.

\section{PEMBAHASAN}

\section{Dekripsi Subyek Penelitian}

Kegiatan pelatihan diikuti oleh orang tua murid dan guru. Berikut ini peserta yang menjadi subyek penelitian.

Tabel. Peserta Pelatihan

\begin{tabular}{|l|l|l|}
\hline No & Nama & Alamat \\
\hline 1 & Nuryanti & Banjardowo \\
\hline 2 & Wasiyem & Ketandan \\
\hline 3 & Samsiyah & Banjardowo \\
\hline 4 & Suprihatin & Ngentak \\
\hline 5 & Titik Weningsih & Ngentak \\
\hline 6 & Laili M & Ngentak \\
\hline 7 & Ning & Banjardowo \\
\hline 8 & Fitri Handayani & Turen Canden \\
\hline 9 & Ifah Nur Utami & Sulang Lor \\
\hline 10 & Upik Sukartiningsih & Sulang Lor \\
\hline 11 & Mujiasih & Ketandan \\
\hline 12 & Novita A & Ketandan \\
\hline 13 & Umi Mardhiyah & Ketandan \\
\hline 14 & Yurom Zahara & Panjang Jiwo \\
\hline 15 & Atik Hidayati & Ketandan \\
\hline 16 & Dyah Indrita L & Gedong \\
\hline 17 & Kristiyanto & Gedong \\
\hline 18 & Siti Solichah & Banjardowo \\
\hline 19 & Yanti Muslimah & Ketandan \\
\hline 20 & Tri Musrifah & Ketandan \\
\hline 21 & Nur Multiwati & Banjardowo \\
\hline 22 & Sunarsih & Ketandan \\
\hline
\end{tabular}


Peserta yang berasal dari Banjardowo sebanyak 6 orang, Ketandan 8 orang, Ngentak 3 orang, Turen Canden 1 orang, Sulang Lor 2 orang, dan Gedong 2 orang.

Sedangkan tutor berjumlah empat orang. Ibu E (50), ahli bidang kewirausahaan, Ibu K(31) bidang pendidikan anak, Bapak T (37) ahli bidang edukasi dan enterpreneur, dan Bapak M (29) ahli PAUD.

\section{Pelaksanaan pelatihan}

Kegiatan Pelatihan ini dilaksananakan dengan prosedur atau langkah-langkah sebagai berikut:

a. Langkah Persiapan (bulan April sampai dengan Juni 2010)

Pada tahap persiapan ini pelaksana pelatihan melaksanakan kegiatan sebagai berikut:

1) Pada bulan April-Juni awal dilakukan kegiatan pengurusan ijin pengabdian dan melakukan pendekatan ke pengurus $\mathrm{KB}$ Cendekia untuk mengidentifikasi permasalahan pembelajaran berkaitan dengan jiwa wirausaha pada anak usia dini. Pada tahap ini juga disepakati kegiatan-kegiatan yang akan dilaksanakan berdasarkan hasil identifikasi masalah.

2) Menyiapkan materi, peralatan, dan fasilitas yang diperlukan dalam kegiatan pelatihan

3) Menyiapkan tugas-tugas yang perlu dilakukan guru selama pelatihan, menyusun instrumen observasi, alat evaluasi, pertanyaanpertanyaan refleksi, dan menyiapkan daftar hadir.

4) Menyusun jadwal pelaksanaan kegiatan pelatihan dan indikator ketercapaian program yang meliputi:

a) Sikap positif dan motivasi yang tinggi dari para guru dan selama mengikuti kegiatan

b) Pemahaman guru dan orang tua terhadap materi pelatihan

c) Peserta minimal $70 \%$ dari seluruh guru dan orang tua yang diundang.

d) Peningkatan jiwa wirausaha pada guru dan orang tua

e) Kemampuan melakukan praktek mengajar dan mengasuh anak agar memiliki jiwa wirausaha

b. Langkah Pelaksanaan (JuliAgustus 2010)

Setelah seluruh aspek kegiatan pelatihan ini dinyatakan siap maka pelaksanaan kegiatan pelatihan segera dilakukan dengan langkah-langkah sebagai berikut:

1) Pelatihan pertama.

Kegiatan dalam bentuk pelatihan dilaksanakan pada hari Selasa, 17 Agustus 2010 di KB Cendekia, diikuti oleh 22 terdiri dari guru dan orang tua siswa. Selain guru dari KB Cendekia pelatihan 
diikuti guru dari PAUD Auladuna dan SPS Dahlia.

Materi pelatihan meliputi:

a) Pembukaan

b) Pemutaran video contoh pembelajaran berbasis jiwa wirausaha di PAUD dan pendidikan dasar. Dan ecara mandiri. dalam video ini dijelaskan bagaimana cara peserta didik melakukan kegiatan secara mandiri dicontohkan dalamsebuah lembaga pendidikan dasar anak diajak makan dan mencuci piring sendiri. Mereka melakukan permainan bersama. Ini memberikan wawasan akan pentingnya kemandirian sejak dini. Peserta antusias menyaksikan video. Kemudian tutor memberikan pertanyaan pancingan yang dijawab oleh peserta terkait dengan kemandirian anak. Dalam diskusi terungkap selama ini anak terbiasa dimanjakan oleh orang tua, hal ini menurut orang tua untuk melindungi anak. Orang tua menjadi memahami bahwasannya terlalu memanjakan anak akan merugikan anak sendiri.

c) Materi "Pentingnya penanaman jiwa wirausaha sejak dini"

Tutor menyampaikan materi dalam bentuk ceramah kemudian dilanjutkan tanya jawab dan diskusi.

Materi "Cara Mendidik anak dalam pembentukan jiwa wirausaha"
Pada materi ini disampaikan ciri dan watak wirausaha sejati. Juga diberi contoh mengenai bentuk mkemandirian dan kreativitas yang dapat diberikan kepada anak sejak dini.

d) Diskusi

e) Evaluasi pelatihan I

Dalam pelatihan ini juga diberikan evaluasi berupa angket dan tes lesan. Peserta diminta menjawab pertanyaan yang diberikan oleh tutor. Apabila masih ada pertanyaan yang kurang tepat tutor akan mengalihkan pada peserta lain. Tutor kemudian memberikan arahan jawaban yang tepat.

\section{2) Pelatihan kedua}

Pelatihan kedua pada hari Minggu, 29 Agustus 2010 di Kelompok Bermain Cendekia. Diikuti oleh 17 peserta.

a) Bernyanyi dan bermain tentang kewirausahaan

b) Pendidikan Kewirausahaan anak usia dini dalam Agama

c) Diskusi

d) Evaluasi pelatihan II

Metode yang digunakan dalam pelatihan ini adalah ceramah, demonstrasi, pemutaran video penanaman jiwa wirausaha di $\mathrm{KB}$, dan role playing.

\section{c. Evaluasi Kegiatan}

Evaluasi kegiatan ini dilakukan pada saat pelatihan dan akhir pelatihan. Hasil monitoring pertama digunakan sebagai bahan evaluasi kegiatan dan sebagai masukan untuk memperbaiki pelaksanaan kegiatan pelatihan

Untuk melihat keberhasilan kegiatan (indikator keberhasilan) 
Menyemai Benih Karakter Wirausaha

maka aspek-aspek yang dimonitoring adalah:

\section{Pembahasan}

Pelatihan telah dilaksanakan untuk menjawab kebutuhan para guru, berdasarkan hasil analisis kebutuhan yang telah dilakukan sebelumnya, terbukti banyak memberikan manfaat yang besar bagi orang tua dan guru terutama dalam bentuk peningkatan pengetahuan dan keterampilan untuk menanamkan jiwa wirausaha sejak dini. Kegiatan pelatihan ini dapat dijadikan sarana untuk meningkatkan kemampuan orang tua dan guru untuk melakukan inovasi-inovasi baru dalam hal internalisasi jiwa wirausaha anak sejak dini.

Materi pelatihan susah sesuai dengan apa yang akan dicapai dalam tujuan pelatihan. Tutor pelatihan adalah orang yang kompeten dalam pelatihan ini. Sebagian besar peserta memiliki sikap positif terhadap pelaksanaan pelatihan. Hal ini dapat ditunjukkan dari hasi observasi sebagian besar (95\%) guru dan orang tua serius dan antusias. Hasil pengamatan menunjukkan bahwa semua peserta terlibat aktif dalam melaksanakan semua tahapan kegiatan pelatihan yang direncanakan. Berdasarkan pengamatan menunjukkan bahwa semua peserta aktif dalam melaksanakan seluruh tahapan kegiatan pelatihan sehingga sebagian besar kegiatan telah dapat menjawab masalah-masalah yang telah dirumuskan. $\begin{array}{ccc}\text { Dilihat } & \text { dari } & \text { tingkat } \\ \text { pemahaman } & \text { terhadap } & \text { materi }\end{array}$ pelatihan menunjukkan bahwa $95 \%$ peserta paham dalam materi pelatihan. Hal ini nampak pada saat diberi pertanyaan tentang materi pelatihan, 95\% berhasil menjawab dengan baik. Pertanyaan materi pelatihan pertama dilakukan saat selesai pelatihanI dan direview lagi pada awal pelatihan kedua.

Peserta 88\% dari seluruh guru dan orang tua yang diundang hadir mengikuti kegiatan. Tiga peserta tidak dapat hadir karena ada kegiatan mendadak yang bersamaan. Sebelumnya ketika dikonfirmasi tutor, pengurus mengatakan mereka dapat mengikuti kegiatan.

Berdasarkan observasi dan wawancara terdapat peningkatan jiwa wirausaha pada orang tua dan guru. Peserta semakin percaya diri ketika diberi tugas oleh instruktur. Ketika pelatihan pertama mereka masih malu-malu dan tidak percaya diri kalau diminta tanggapan dan pertanyaan, namun dipelatihan ke dua mereka sudah percaya diri, bahkan berani untuk menawarkan dagangan sebagai wujud adanya jiwa wirausaha.

Dilihat dari jiwa wirausaha menunjukkan bahwa semua peserta nampak antusias dan percaya diri untuk berlatih mempraktekkan materi yang diterima dalam pembelajaran di kelas maupun saat mengajar anak didiknya. Guru dan orang tua menunjukkan kemampuan yang positif terutama 
dalam penanaman jiwa wirausaha kepada putra putrinya.

Kegiatan pelatihan ini terlaksana dengan baik karena didukung oleh beberapa factor, antara lain:

1. Semangat dan motivasi para peserta untuk maju dan terus meningkatkan kemampuan mengasuh siswa dan anak, khususnya dalam upaya meningkatkan kualitas belajar dan pembelajaran bagi anak/peserta didiknya.

2. Dukungan (support) pengurus KB Cendekia dan kepala sekolah serta untuk kelancaran kegiatan-kegiatan dalam bentuk pemberian dukungan fasilitas tempat dan kegiatan.

Walaupun terdapat beberapa faktor pendukung, pelaksanaan pelatihan ini tidak terlepas dari adanya faktor penghambat atau kendala yang dihadapi, yaitu: waktu yang relative panjang untuk mempersiapkan materi pembelajaran terutama untuk materi yang baru, serta,adanya kegiatan yang bersamaan dengan kegiatan guru sehingga ada beberapa peserta yang diundang tidak dapat datang.

Data kegiatan penelitian ini dikumpulkan dengan menggunakan teknik observasi. Data yang diungkap meliputi: proses kegiatan, respon peserta, dan pembimbingan. Selain melalui observasi, data juga dilengkapi melalui wawancara terbuka kepada peserta berkenaan dengan suasana hati serta berbagai hal yang berkaitan dengan berlangsungnya kegiatan. Teknik analisis data dilakukan dengan deskriptif dengan menggunakan presentase.

\section{E. PENUTUP}

\section{Kesimpulan}

Mengacu pada pembahasan dapat diambil kesimpulan:

a. Hasil penelitian menunjukkan: Sebagian besar peserta memiliki sikap positif terhadap pelaksanaan pelatihan. Hal ini dapat ditunjukkan dari hasil observasi dan wawancara : a) Sebagian besar peserta memiliki sikap positif terhadap pelaksanaan pelatihan yang diunjukkan dari hasil observasi sebagian besar (95\%) guru dan orang tua serius serta antusias. Hasil pengamatan menunjukkan bahwa semua peserta terlibat aktif dalam melaksanakan semua tahapan kegiatan pelatihan yang direncanakan. Berdasarkan pengamatan menunjukkan bahwa semua peserta aktif dalam melaksanakan seluruh tahapan kegiatan pelatihan sehingga sebagian besar kegiatan telah dapat menjawab masalah-masalah yang telah dirumuskan. b) Dilihat dari tingkat pemahaman terhadap materi pelatihan menunjukkan bahwa $95 \%$ peserta paham dalam materi pelatihan. Hal ini nampak pada saat diberi pertanyaan tentang materi, 95\% berhasil menjawab dengan baik. c) dalam pelatihan peserta $88 \%$ dari seluruh guru dan orang tua yang diundang mengikuti kegiatan. d) Berdasarkan observasi dan wawancara 
terdapat peningkatan jiwa wirausaha pada orang tua dan guru. Peserta semakin percaya diri ketika diberi tugas oleh instruktur/tutor. e) Dilihat dari jiwa wirausaha menunjukkan bahwa semua peserta nampak antusias dan percaya diri untuk berlatih mempraktikkan materi yang diterima dalam pembelajaran di kelas maupun saat mengajar anak didiknya.

b. Faktor pendukung pelatihan adalah: 1) Semangat dan motivasi para peserta untuk maju dan terus meningkatkan kemampuan mengasuh siswa dan anak, khususnya dalam upaya meningkatkan kualitas belajar dan pembelajaran bagi anak/peserta didiknya. 2) Dukungan (support) pengurus KB Cendekia dan kepala sekolah serta untuk kelancaran kegiatan-kegiatan dalam bentuk pemberian dukungan fasilitas tempat dan kegiatan. Faktor penghambat yaitu: waktu yang relative panjang untuk mempersiapkan materi pembelajaran terutama untuk materi yang baru, serta,adanya kegiatan yang bersamaan dengan kegiatan guru sehingga ada beberapa peserta yang diundang tidak dapat datang.

2. Saran

Berdasarkan beberapa simpulan tersebut dapat disampaikan saran sebagai berikut:

a. Bagi peserta, Diharapkan peserta bersedia menerapkan secara kontinyu penanaman jiwa wirausaha sejak dini di kelas guru dan orang tua yang telah mengikuti kegiatan pelatihan hendaknya terus selalu meningkatkan kualitas pembelajaran dengan memanfaatkan media dan sumber-sumber belajar dalam pembelajaran sebagaimana telah dicontohkan melalui kegiatanpelatihan ini.

b. Perlu penelitian lanjutan mengenai efektivitas pelatihan kewirausahaan sejak dini tidak hanya ketika berlangsung pelatihan, namun pada saat aplikasi di kelas dan dampak dari pelatihan.

\section{Daftar Pustaka}

Buchari Alma (2007). Kewirausahaan. Bandung: Alfabeta

Elizabeth B. Hurlock (2005). Perkembangan Anak (Diterjemahkan Meitasari Tjandrasa). Jakarta: Erlangga

http://www.bappekab.sidoarjokab. go.id $/$ ?file=04-doc-hsl-kajian/rip$\underline{\mathrm{ukm} \cdot \mathrm{htm}})$

http://www.geocities.com/agus_le cturer/kewirausahaan/definsi_kew irausahaan.htm.

Ichsan S. Puta \& Ariyanti Pratiwi (2005). Sukses Dengan Soft Skill. Bandung: ITB

Leslie Rae (1990). Mengukur Efektivitas Pelatihan. Jakarta: PT Pustaka Binaman Pressindo 
| Kiromim Baroroh

Lincoln, Y.S \& Guba. (1985). Patton, M. Q. (1982). Qualitative Naturalistic inquiry. London: Sage evaluation methods. London: Sage Publication Publications

Miles, M.B. \& Huberman. A.M. Robert D.Hisrich, Micahel P.Peters, (1994). Qualitative data analysis. Dean A.Shepherd (2010). London: SAGE Publication Enterpreneurship. Seventh Edition.

Moleong, L.J. (2004). Metodologi New York: McGraw Hill

penelitian kualitatf Bandung: PT

Remaja Rosdakarya 